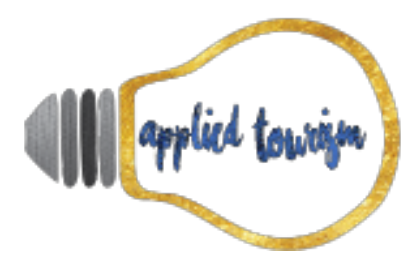

Volume 3, número 1, 2018, p. 93-126

\title{
GESTÃO DA EXPERIÊNCIA EM SERVIÇO DE HOSPITALIDADE: Análise das Avaliações de Hospedagens do Village Confort Hotel e Flat em. João Pessoa / PB
}

Thiago Vinícius Pereira de Brito

Bacharel em Turismo

Recepcionista no Village Confort Hotel e Flats vinicius.brito@yahoo.com.br

Márcia Félix da Silva

Mestra em Administração e Doutoranda em Recursos Naturais Universidade Federal da Paraíba - UFPB mfelixufpb@gmail.com

Nicole Cavalcanti Silva

Mestranda em Recursos Naturais Universidade Federal de Campina Grande - UFCG nickolecavalcanti@gmail.com

Recebido: 28 de junho, 2017

Aprovado: 03 de outubro, 2017

\section{RESUMO}

Nos últimos anos, o mercado hoteleiro brasileiro vem passando por importantes transformações para atender aos desejos de um consumidor bem informado e, por consequência, bem mais exigente. A busca por mais qualidade nos serviços oferecidos pelos meios de hospedagem, aliada à disseminação do uso da Internet têm contribuído para essa mudança de comportamento do consumidor que busca obter uma experiência positiva em relação à satisfação dos seus desejos e expectativas. Nesse sentido, este estudo buscou analisar a relação da experiência em serviços de hospitalidade e as diretrizes tomadas pelo Village Confort Hotel e Flat, localizado em João Pessoa$\mathrm{PB}$, a partir dos comentários (positivos e/ou negativos) registrados pelos hóspedes, por meio dos mecanismos de avaliação dos serviços. A pesquisa realizada foi do tipo exploratória, descritiva de abordagem quanti-qualitativa, conduzida sob a forma de um estudo de caso. Foram coletados dados primários e secundários em sítios de compras de hospedagem na Internet e no próprio estabelecimento através de fichas avaliativas e do feedback eletrônico. Os resultados mostraram que diante da intangibilidade do produto turístico, a experiência em serviços de hospitalidade é influenciada pela maneira como os gestores direcionam ações visando solucionar problemas ou maximizar oportunidades quando tem o conhecimento das reclamações e dos elogios apresentados pelos hóspedes.

Palavras-chaves: Estratégias Competitivas, Gestão de Eventos. Turismo de Eventos. 


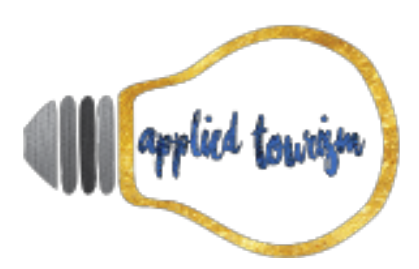

Volume 3, número 1, 2018, p. 93-126

\section{INTRODUÇÃO}

Na decisão de compra de algum bem ou serviço diversos fatores podem influenciar positiva ou negativamente o consumidor. Para que uma empresa alcance seus objetivos de transformar um consumidor potencial em um consumidor real, a utilização das ferramentas do marketing é indispensável. A partir da compreensão do comportamento do consumidor, da utilização de novas tecnologias e da relação com os demais stakeholders, as empresas poderão elaborar estratégias e diretrizes para seu posicionamento frente à concorrência.

No mercado turístico registra-se ainda uma figura constantemente presente nas relações entre as empresas e seus clientes/consumidores: o intermediário - o operador de turismo fazendo contato com os meios de hospedagem, restaurantes, transportes, receptivos, dentre outros serviços necessários à oferta de serviços que possam gerar experiências positivas para o cliente/consumidor.

Para Cooper (2007), apesar da possibilidade de aquisição direta do produto turístico [sobretudo com a disseminação da Internet], os clientes/consumidores ainda utilizam bastante os serviços dos intermediários por estes adotarem estratégias de redução de custos e dos entraves burocráticos na oferta de bens e serviços turísticos e, em muitos casos, o contato direto entre os clientes potenciais e a empresa acaba comprometendo as negociações, evidenciando falhas no relacionamento e, nesse caso, as agências intermediadoras influenciam diretamente no mercado turístico ao estabelecerem relações entre o consumidor, o destino e o fornecedor do produto, através de sólidos e estruturados canais de distribuição.

Por muito tempo, os intermediários eram representados pelas agências e operadoras de turismo. Atualmente, com a disseminação das tecnologias da informação, a Internet passou a ter um papel significativo no desenvolvimento do mercado de compras de produtos turísticos online, a exemplo, dos sites Expedia.com ${ }^{\mathrm{TM}}$, um dos principais intermediários via

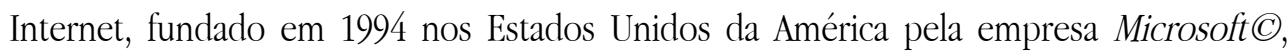




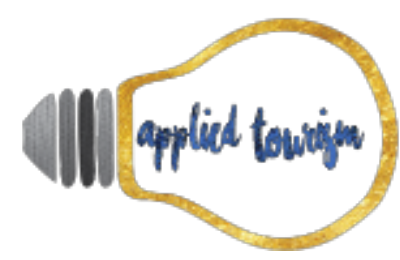

Volume 3, número 1, 2018, p. 93-126

presente em aproximadamente 30 países e o Booking. com $^{T M}$, conhecido como líder mundial em distribuição de reservas pela Internet, com atuação em 223 países e territórios, com página traduzida para mais de 40 idiomas. Esses dois intermediários buscam oferecer comodidade, preço baixo e facilidade de reservas de hospedagem a qualquer momento, sem burocracia e com garantias.

No Brasil, alguns gestores de meios de hospedagens estão mais preocupados com a maximização da riqueza dos acionistas, concedendo pseudovantagens quando da oferta de serviços para alcançar esse objetivo ou mesmo aumentando os esforços em branding para o fortalecimento da marca junto aos seus clientes e fornecedores. Entretanto, poucos são os estabelecimentos que realmente se preocupam em entender a hospedagem como uma maneira de servir e buscar, efetivamente, adequar o serviço para atender às necessidades reais do consumidor. Portanto, o caminho mais indicado para a construção de relacionamentos sólidos entre o consumidor e o meio de hospedagem é buscar atender às suas expectativas através da experiência com a marca, cabendo ao estabelecimento a gestão eficiente dessa experiência que resulte na percepção positiva do consumidor.

Nesse sentido, este estudo teve como objetivo analisar a gestão da experiência em serviços de hospitalidade no Village Confort Hotel e Flat, localizado em João Pessoa, capital do Estado da Paraíba, a partir do levantamento e análise dos comentários [positivos e negativos] registrados pelos hóspedes por meio dos instrumentos de avaliação dos serviços frequentemente utilizados por essa rede de hotéis: pesquisa interna [através de fichas avaliativas] avaliações disponibilizadas nos sites da Booking. .om $^{T M}$ e da TripAdvisorC. A gestão da experiência em serviços de hospitalidade tem por finalidade, mostrar a importância das avaliações dos serviços pelos hóspedes e suas percepções quanto ao caráter ordinário e extraordinário de suas estadas no local de destino. Por sua vez, a escolha do tema pelos pesquisadores partiu das inquietações relacionadas à ânsia de conhecer as práticas de gestão de experiência em serviços de hospitalidade, considerando que a qualidade dos serviços prestados pelo meio de hospedagem influencia diretamente na experiência dos hóspedes. 


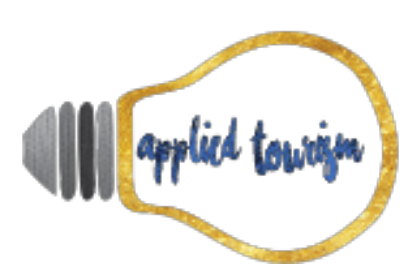

Volume 3, número 1, 2018, p. 93-126

Assim, compreender parte do processo da hospitalidade é fundamental para a comunidade acadêmica e para a empresa envolvida, propiciando diversas possibilidades de discorrer sobre o assunto através dos estudos da gestão da experiência como parte de um sistema maior e mais complexo que caracteriza a hospitalidade.

\section{REVISÃO DE LITERATURA}

\subsection{A hotelaria como produto turístico}

O produto turístico em sua maioria está relacionado a bens tangíveis (gastronomia, museus, praias, monumentos, dentre outros) e intangíveis (cultura, cerimoniais, crenças, costumes, dentre outros), o que afeta as emoções e a experiência de cada consumidor. Dentre os mais diversos produtos turísticos está a indústria hoteleira, elemento importante para a manutenção da atividade turística.

Beni (2006), afirma que um hotel é uma empresa de prestação de serviços que se diferencia completamente de outros estabelecimentos industriais ou comerciais, pois ao mesmo tempo em que presta serviços também oferecem produtos.

Para Castelli (2016a), os meios de hospedagem são organizações que oferecem alojamento a uma clientela indiscriminada mediante pagamento de uma taxa (diária). Nessa perspectiva, cabe ao consumidor direcionar as suas motivações pessoais na escolha do meio de hospedagem adequado à sua necessidade.

Assim, as empresas hoteleiras podem ser classificadas, quanto ao seu tamanho, em pequenas, médias e grandes, e o parâmetro que fundamenta essa classificação pode ser o apartamento, o número de leitos ou a receita anual (Castelli, 2016a). Todavia, existem outros critérios que podem diversificar a oferta hoteleira como a relação com seu público, o tipo de serviço oferecido e a estrutura física. 


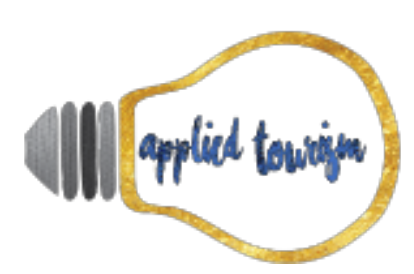

Volume 3, número 1, 2018, p. 93-126

Cabe ressaltar que, vender o serviço hoteleiro não é apenas vender o hotel em si e sua estrutura, mas uma série de fatores e elementos que compõem um mix sensorial, levando o consumidor a avaliar a presteza de tal oferta.

Holbrook (2000), avalia que a experiência nos serviços de hospitalidade como os hotéis é fator dominante, e que a tomada de decisão é influenciada pelo imaginário, pelas emoções e pelo prazer. Tais atributos possibilitam que o estabelecimento observe o comportamento do consumidor e sua relação com o proposto pela empresa, viabilizando compreender as fases da experiência de consumo, antes da tomada de decisão sobre seu posicionamento e linhas de ações.

Sob essa perspectiva, é necessário identificar os aspectos que distinguem uma experiência ordinária de uma experiência extraordinária, considerando três fases importantes: o préconsumo, a compra/consumo e os resultados (Barbosa et al., 2011). Nessa perspectiva, os resultados possibilitam observar, a partir da receita, da reincidência em utilizar os mesmos serviços em momentos posteriores e da análise das sugestões e críticas, o grau de satisfação e lealdade do consumidor em relação ao hotel.

Conforme destacam Branco, Ribeiro \& Tinoco (2010), as empresas buscam se posicionar no mercado a partir da satisfação de seus clientes mediante a qualidade de seus produtos ou serviços oferecidos. Corroborando com esse pensamento, Fitzsimmos \& Fitzsimmos (2014), destacam que, mediante a intangibilidade que os serviços de hospedagem possuem, a avaliação da qualidade surge ao longo do processo de prestação do serviço, que geralmente ocorre no encontro entre um cliente e um funcionário da linha de frente.

Vale ressaltar que, não há consenso a respeito do conceito de qualidade e diversos autores expressam a ideia de maneira diferente. Para Castelli (2005b), o conceito de qualidade na hotelaria pode ser observado no que ele caracteriza como "momento da verdade", quando o hospede irá examinar se está recebendo o que foi prometido com tudo aquilo que ele tem direito no momento da interação entre ele e os funcionários do hotel. 


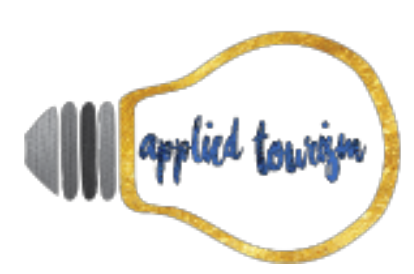

Volume 3, número 1, 2018, p. 93-126

A observação do modo como o serviço é ofertado, permite presumir que quaisquer melhorias do serviço ou favorecimento ao consumidor podem ser caracterizadas como qualidade (Daft, 2009). Para que a satisfação do cliente com o produto que the é apresentado ocorra em sua plenitude, deve haver uma relação de equidade, sendo a qualidade um atributo que atenda aos interesses do consumidor, ou seja, a qualidade se refere à adequação ao uso (Oliveira, 2008).

O que se pode observar é que o bem ou serviço, quando corretamente definido e oferecido com atributos de qualidade, deve corresponder às motivações e expectativas do consumidor. Assim, a qualidade se torna um diferencial competitivo que poderá influenciar positivamente na consolidação das relações entre o consumidor e a empresa, fortalecendo o relacionamento entre ambas as partes, agregando valor ao produto e consequentemente viabilizando a satisfação e fidelização do cliente, nesse caso, em relação aos serviços de hospitalidade.

\subsection{A qualidade dos serviços de hospitalidade}

A hospitalidade corresponde ao fenômeno de bem receber, não se restringindo à cortesia ou cordialidade em si, mas a uma série de fatores que corroboram para o bem-estar ou desfruto do prazer propriamente dito daqueles que se servem. Sendo assim compreendese que a hospitalidade é a composição de bens-tangíveis (camas, cobertores, drinks, souvenires, dentre outros) e bens-intangíveis (cortesia, satisfação, felicidade, dentre outros).

O termo hospitalidade pode ser visto sob a perspectiva comercial e econômica, levando-se em consideração a oferta de bens e serviços e não apenas os seus consumidores. Para Gonzáles, Ramos \& Amorim (2005), o termo 'hospitalidade' emergiu como o modo pelo qual os hoteleiros e fornecedores de alimentos e bebidas gostariam que seu setor fosse visto. Essencialmente, a hospitalidade se compõe de dois tipos de serviços distintos: a 


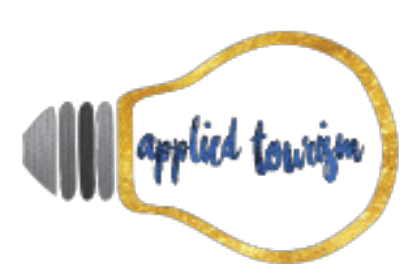

Volume 3, número 1, 2018, p. 93-126

provisão de acomodação noturna para pessoas que estão longe de casa e a provisão de alimentos para as que comem fora de casa.

Por sua vez, Lashley \& Morrison (2004), afirmam que a hospitalidade não está apenas no fornecimento de alimentos e bebidas ou na hospedagem, mas sim em outros fatores e atores envolvidos, ou seja, a hospitalidade envolve uma mistura harmoniosa da gastronomia, da oferta de abrigo em um ambiente físico e do comportamento e atitudes [cordiais] dos envolvidos.

Corroborando com esse pensamento, Trigueiro (2003), propõe que a hospitalidade trata de uma troca humana contemporânea, assumida voluntariamente e concebida para aumentar o bem-estar mútuo das partes envolvidas mediante oferta de acomodação, conforto, alimento ou bebida.

Nesse sentido, na hospitalidade, a hospedagem se configura como principal produto/serviço oferecido ao turista. De fato, o turista que se desloca para o destino de visitação por mais de um dia deverá fazer uso de um meio de hospedagem, desde o mais simples ao mais sofisticado, dos mais bem elaborado até o mais rústico. O fator em comum é que ele necessitará de acomodação a seu critério, seja a escolha realizada através do contato direto com o estabelecimento, seja através de um intermediário.

Campos \& Gonçalves (1998), afirma que a hotelaria no cenário nacional, permaneceu quase que inerte no período de 1970 a 1990, e atendia aos gostos dos proprietários. Em sua maioria os estabelecimentos não possuíam diferenciações, não passando de imitação de modelos de outros hotéis, claro que com exceções, porém o cliente não era o foco principal da relação comercial.

Após a década de 1990, o mercado hoteleiro nacional apresentou aumento significativo na sua participação. A visão de mercado não permaneceu inerte e logo esse modelo de se fazer hotelaria se adaptou a uma nova relação de oferta e demanda, onde, além da grande 


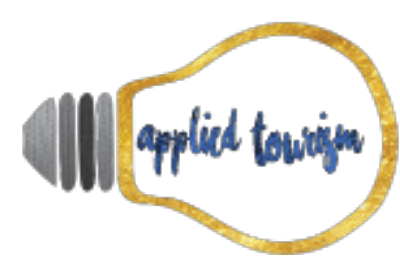

Volume 3, número 1, 2018, p. 93-126

quantidade de estabelecimentos com baixos custos e poucos serviços, ocorreu a mudança no comportamento do consumidor: a grande oferta do produto [meios de hospedagem] fez com que o consumidor se tornasse mais exigente e cada vez mais a qualidade passou a ser critério decisivo, influenciando diretamente na percepção sobre o serviço ofertado mesmo que de forma subjetiva, ou seja, o "consumidor procura o produto que mais atende às suas necessidades, desejos e expectativas" (Campos \& Gonçalves, 1998, p. 195).

Essa mudança de comportamento do consumidor, proporcionada principalmente pela facilidade de acesso à informação, sobretudo com a disseminação da Internet e pelos avanços da tecnologia da informação que propiciou a oferta de novas ferramentas que facilitam a comunicação nas relações comerciais, trouxe importantes contribuições para a evolução do mercado hoteleiro, a exemplo dos sítios de vendas online que possibilitam que consumidores potenciais tomem a decisão de compra sem a participação de intermediários. Atentos a essas mudanças de comportamento, os intermediadores passaram a oferecer vantagens na hora de realizar as reservas, como flexibilidade de horário de compra, formas de pagamento, além de grande credibilidade ao abrir espaço para que os clientes possam expor suas experiências de maneira livre e voluntária.

De fato, a praticidade no acesso à informação gera impactos diretos nos meios de hospedagem, tornando imperativa a necessidade de gerenciamento da experiência dos consumidores no processo de tomada de decisão, para que se possam promover ações corretivas na oferta de serviços e alinhar o planejamento estratégico organizacional com as expectativas desses consumidores, devendo ser considerado que as críticas de caráter ordinário [ocorrências rotineiras] ou extraordinário [ocorrências excepcionais] são fundamentais para o equilíbrio e a dinamização na prestação de serviço, propiciando a melhoria do posicionamento da empresa no mercado e o fortalecimento da sua imagem.

Observa-se que todo o conceito de hospitalidade se baseia no conhecimento empírico, pela análise do comportamento e da experiência em estabelecimentos que prestam serviços de hospitalidade, como também é um conceito influenciado pela observação do 


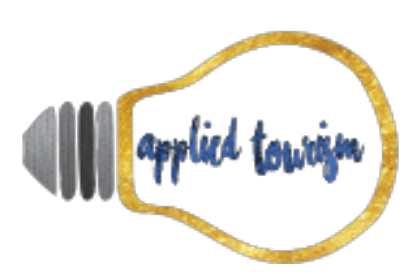

Volume 3, número 1, 2018, p. 93-126

comportamento dos fornecedores desse serviço. Então, considera-se que a hospitalidade parte da observação do comportamento e da relação de troca humana e que essa relação pode ser caracterizada como contemporânea, agradável, voluntária e mutuamente benéfica.

Sob essa perspectiva, a gestão da experiência em serviços de hospitalidade é influenciada interna e externamente por fatores que vão além do monitoramento do fornecimento de um serviço de hospedagem e de seus envolvidos ou da percepção do consumidor acerca dos serviços prestados, pois ela transcende a experiência em si, e se envolve nos procedimentos comunicacionais entre o pessoal operacional e consumidores potenciais e reais.

Do ponto de vista do consumidor - aquele que desfruta dos serviços que lhes são prestados - a percepção da qualidade em serviços de hospitalidade dependerá da avaliação da sua experiência, cabendo-lhe, portanto, mensurar o que a empresa propõe e o que de fato foi ofertado e à empresa cabe o gerenciamento das informações relativas à satisfação ou à insatisfação desses consumidores, para que possa implementar ações estratégicas que visem à melhoria da qualidade dos serviços. Nesse sentido, estabelecer relacionamentos saudáveis e produtivos, a partir da gestão da experiência, configura-se como um valioso canal de comunicação entre as empresas e seus consumidores.

\subsection{Do Marketing de Relacionamento à Gestão da Experiência}

O marketing pode ser visto como um processo de construção de relacionamentos e, conforme Kotler \& Keller (2012a), para que esses relacionamentos sejam cultivados é necessário que a empresa utilize estratégias que maximizem o valor do produto: o fruto do relacionamento entre a empresa e o cliente é a consolidação da imagem através da confiança.

Nesse contexto, percebe-se que a confiança é construída a partir da satisfação do cliente, compreendida como o resultado ou a sensação de prazer ou de desapontamento com o 


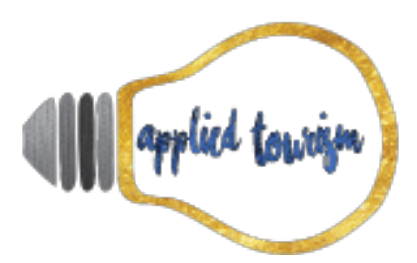

Volume 3, número 1, 2018, p. 93-126

produto resultante da comparação entre o desempenho (resultado) percebido de um produto ou serviço e as expectativas do comprador (Kotler \& Keller, 2012a).

Assim, a percepção da satisfação do cliente é fundamental na hora de direcionar ações corretivas de comunicação interna e externa, visto que, o relacionamento entre a empresa e o cliente pode sofrer interferência de situações ocasionais ou de ações e fatores específicos, o que não caracteriza supor que o rompimento nos relacionamentos ou dificuldade em cultivá-los, seja fruto de toda uma experiência abaixo da expectativa do consumidor.

Como forma de direcionar a tomada de decisão e a adoção de medidas corretivas, Cadottte \& Turgeon (1988), afirmam que é fundamental a identificação de atributos que afetem a satisfação do cliente em relação à qualidade do produto ou serviço, pois é a remuneração atribuída por eles aos bens e serviços que garantirão a existência e manutenção do estabelecimento.

Buscando estabelecer vínculos mais fortes com os clientes, as empresas passaram a gerenciar cuidadosamente informações detalhadas [e valiosas] sobre eles através do Gerenciamento do Relacionamento com o Cliente (Customer Relationship Management CRM), incluindo-se todos os pontos de contato do cliente com a empresa e, nesse caso, estendendo-se desde a experiência em si até uma comunicação pessoal ou de massa, a exemplo de reservas, check-in e check-out, programas de fidelidade, serviço de quarto, de escritório, academia de ginástica, lavanderia, restaurante e bar, no caso específico dos hotéis (Kotler \& Keller, 2007b).

Outra ferramenta que também tem sido bastante útil para os gestores é a de Gerenciamento da Experiência do Cliente (GEC). Diferentemente do CRM, a GEC não é exatamente um conceito de marketing, mas de gestão orientada por processo e não por resultado, indo além do CRM, não se limitando apenas ao registro de transações com o cliente, mas a construção de boas relações com os clientes (TISCHELER et. al., 2012). 


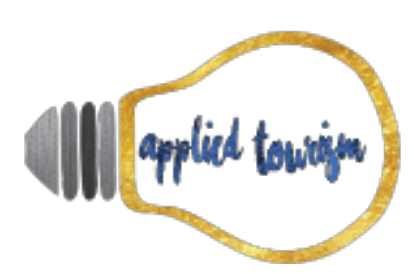

Volume 3, número 1, 2018, p. 93-126

De acordo com Schimitt (2004) apud Tischeler et al. (2012), a estrutura da GEC, consta de cinco etapas básicas: 1) análise do mundo experiencial do cliente [análise do contexto do negócio]; 2) construção de uma plataforma experiencial [implementação da ferramenta e coordenação de ações de marketing, comunicação e inovações]; 3) projeção da experiência da marca no mercado [aspectos mercadológicos do produto], 4) estruturação da interface do cliente [criação de intercâmbios apropriados e interativos com os clientes]; 5) compromisso com a inovação contínua [implementação de melhoria contínua].

Sob esse enfoque, o instrumento mais indicado e utilizado pelas empresas para a percepção das falhas é o registro de reclamações e algumas delas abrem mecanismos de registros de elogios, reclamações, sugestões e avaliações, tanto no próprio estabelecimento, com a utilização de questionários de pesquisa de satisfação, quanto através de sítios na Internet.

\section{PROCEDIMENTOS METODOLÓGICOS}

A pesquisa realizada foi do tipo exploratória, descritiva de abordagem quanti-qualitativa, conduzida sob a forma de um estudo de caso, realizada no Village Confort Hotel e Flat, localizado em João Pessoa, capital do Estado da Paraíba, com o objetivo de fazer uma análise dos relatos das experiências de 279 sujeitos que utilizaram os serviços de hospedagem do hotel, no período de janeiro a março do corrente ano e que registraram suas experiências nos sites do Booking.com ${ }^{T M}$ (2017), no TripAdvisor@ (2017) e através de fichas avaliativas disponibilizadas no próprio hotel, além do feedback eletrônico da empresa que é gerenciado pelo Diretor Executivo. Todas essas fontes de dados resultaram em uma amostra não probabilística por conveniência.

Também foi utilizada como técnica de investigação, a observação participante considerando o vínculo profissional de um dos autores com $o$ Village Confort Hotel e Flat, o que permitiu a realização de conversas informais no decorrer da pesquisa com o Gerente Geral do estabelecimento, com a Gerente Comercial, com funcionários da recepção e com o Diretor Executivo que forneceram informações sobre as ações do hotel em relação aos feedbacks 


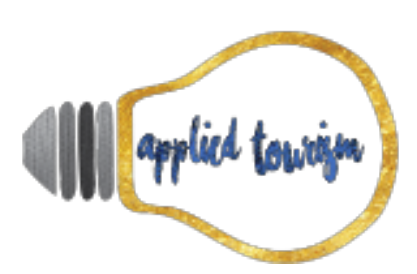

Volume 3, número 1, 2018, p. 93-126

dos registros das experiências pelos hóspedes e que serviram de subsídios para o embasamento da pesquisa.

Para facilitar a tabulação e posterior análise dos dados, as informações registradas pelos hóspedes foram categorizadas de acordo com os atributos estabelecidos pelos pesquisadores, quais sejam: qualidade dos serviços [comodidade, conforto, limpeza, localização, atendimento, custo benefícios, café da manhã, dentre outros] e estrutura [tamanho do quarto, estrutura geral do hotel, instalações, dentre outros], levando-se em consideração os relatos das percepções positivas e negativas em relação à experiência de hospedagem.

Os dados foram tabulados e processados em planilha eletrônica Excele, posteriormente, os resultados foram analisados pelos pesquisadores que apresentaram sugestões e recomendações para o gerenciamento da experiência que possam promover a melhoria da qualidade dos serviços prestados pelo hotel.

\section{APRESENTAÇÃO E ANÁLISE DOS RESULTADOS}

O objetivo desta seção foi o de discorrer sobre a percepção dos clientes em relação à experiência vivenciada no Village Confort Hotel e Flat a partir da coleta dos dados registrados nos comentários, críticas e avaliações positivas e negativas no período posterior à estada no hotel. Os dados foram categorizados de acordo com os atributos relativos à qualidade dos serviços oferecidos pelo hotel e relativos à sua estrutura física, obtendo-se as seguintes variáveis: comodidade, instalações, limpeza, conforto, localização, funcionários, emocional, custo-benefício, café da manhã, estrutura física, tamanho do quarto, atendimento às solicitações dos hóspedes.

Os atributos relativos à comodidade, instalações, estrutura física e conforto foram agrupados para facilitar a quantificação dos dados levando-se em consideração a 


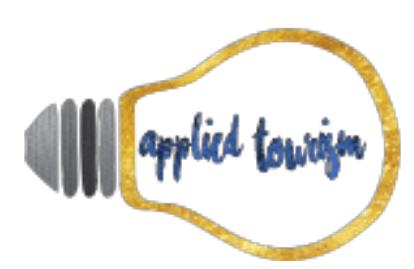

Volume 3, número 1, 2018, p. 93-126

compreensão dos itens que poderiam vir a ser considerados pertencentes a cada variável (Quadro 01).

Quadro 01 - Variáveis dos atributos

\begin{tabular}{|l|l|l|l|}
\hline Comodidade & Instalações & Estrutura Física & Conforto \\
\hline Internet & WC & Tamanho dos Banheiros & Cama \\
Ar condicionado & Cortinas & Acabamento dos cômodos & Toalhas \\
TV & Decoração & Acústica dos Quartos & Carpete/Tapetes \\
Estacionamento & Ralos & Elevadores & Produtos Químicos \\
Manobrista & Exaustor & Acessibilidade & Música Ambiente \\
Alimentação & Pintura & Escadaria & \\
Computador & Piso & Área de Lazer & \\
Mensageiro & Fechadura & Corta incêndio & \\
Sala de Reuniões & & Tamanho dos quartos & \\
Cofre nos quartos & & & \\
Lavanderia & & & \\
\hline
\end{tabular}

Fonte: Pesquisa dos autores (2017).

\subsection{Resultado das análises do feedback eletrônico}

Com base na análise da coleta de dados fornecidos através do feedback eletrônico mensagens enviadas via e-mails pela direção do hotel para os hóspedes - foram obtidas informações relativas à satisfação dos clientes sobre a experiência de hospedagem. Nesse sentido, o gráfico 01 apresenta as respostas dos clientes em relação aos atributos de qualidade dos serviços e estrutura do hotel. 


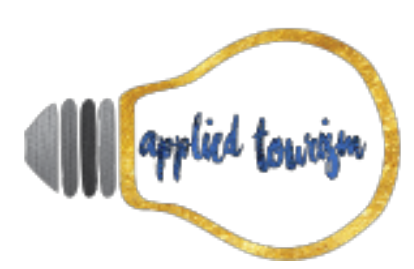

Volume 3, número 1, 2018, p. 93-126

Gráfico 01 - Aspectos da avaliação positiva de satisfação em relação à hospedagem

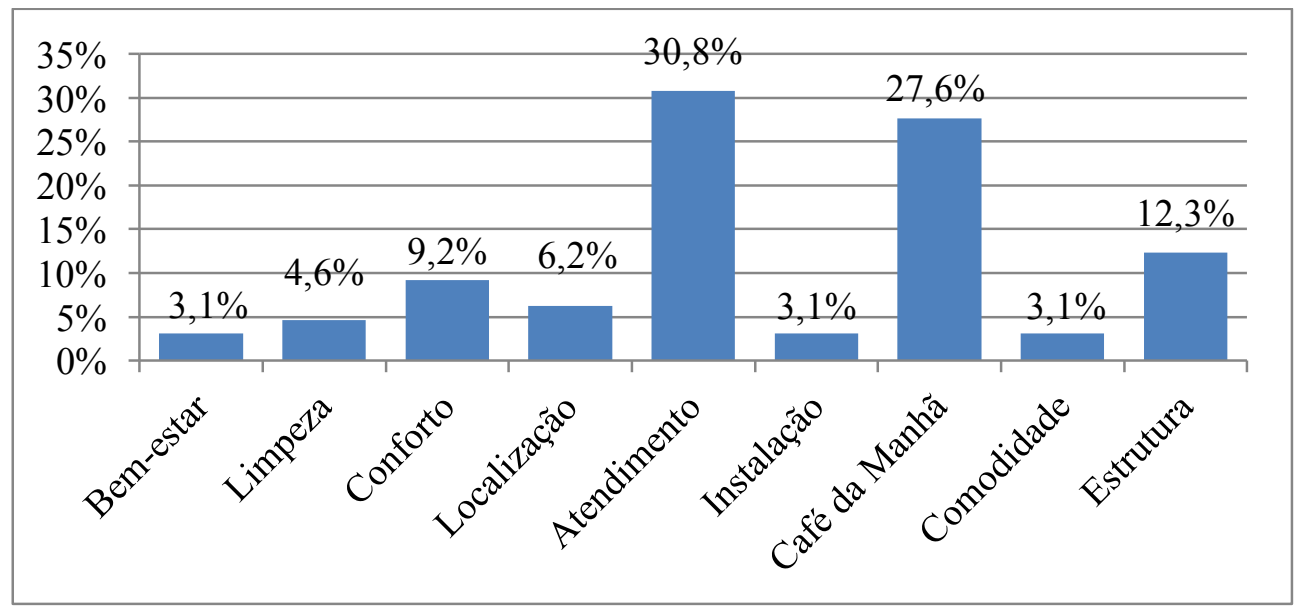

Fonte: Pesquisa dos autores (2017).

Conforme observado, os dados do gráfico 01 mostram que, 30,8\% dos hóspedes mencionaram o atendimento dos funcionários como atributo que proporcionou maior satisfação. Para 27,6\% dos respondentes, o café da manhã [com opções variadas] vem em seguida como atributo de satisfação. Em relação à estrutura 12,3\% dos respondentes consideram que a estrutura do hotel é satisfatória.

Outros atributos foram mencionados pelos pesquisados como fatores de satisfação com a experiência de hospedagem: conforto $(9,2 \%)$, localização - proximidade com shoppings, restaurantes, orla marítima $(6,2 \%)$-, limpeza dos ambientes (4,6\%), comodidade $(3,1 \%)$, bem-estar emocional (3,1\%), instalações (3,1\%).

Ressalta-se que os atributos aqui elencados foram mencionados 65 vezes em um total de 35 e-mails respondidos. A pesquisa também buscou identificar os atributos avaliados negativamente pelos hóspedes, obtendo-se os resultados seguintes. 


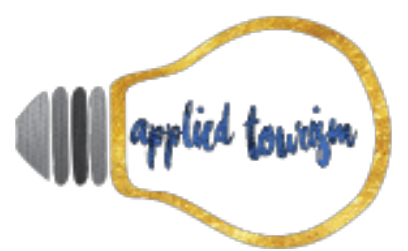

Volume 3, número 1, 2018, p. 93-126

Gráfico 02 - Aspectos da avaliação negativa de satisfação em relação à hospedagem

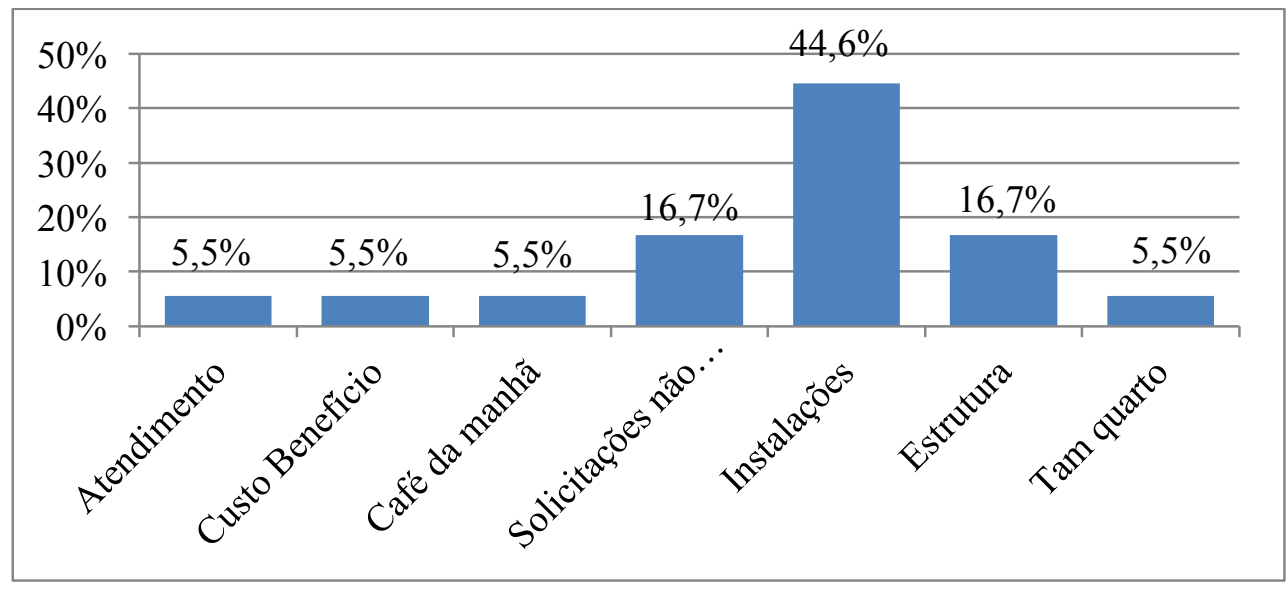

Fonte: Pesquisa dos autores (2017).

Conforme observado no gráfico 02 , dentre os pesquisados $16,7 \%$ atribuiu a sua insatisfação com a hospedagem no hotel à estrutura [tamanho dos banheiros, acabamento dos cômodos, acústica dos quartos, elevadores, rampa de acesso, escadaria, área de lazer e corta incêndio]. Nesse aspecto, alguns hóspedes mencionaram ainda a dificuldade em utilizar a garagem devido à disposição das vagas que, em alguns casos, impossibilita a sua utilização [dependendo do tamanho do veículo] ou que a trava do banheiro só fechava por dentro. Também foi de 16,7\% o percentual de respondentes que tiveram algum tipo de solicitação não atendida, embora não tenha sido especificada.

Para 44,6\% dos pesquisados, a avaliação negativa está relacionada às instalações: WC, cortinas, decoração, ralos, exaustor, pintura, piso e fechadura das portas.

Registrou-se, portanto, a necessidade de se estabelecer canais de comunicação interna para que, mediante as solicitações/reclamações dos hóspedes, o hotel haja de forma corretiva, buscando solucionar os problemas ou mesmo se antecipando a eles, além de buscar dialogar com o hóspede caso a viabilidade em atender às suas solicitações/reclamações não seja possível no momento, a exemplo da disposição e tamanho das vagas na garagem por se tratar de um problema que está diretamente relacionado ao projeto arquitetônico do prédio. 


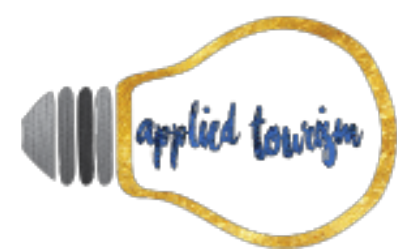

Volume 3, número 1, 2018, p. 93-126

Em geral, observou-se que as críticas negativas em relação aos atributos pesquisados, não se sobrepuseram ao número de críticas positivas, apresentando um total de 18 menções nas mensagens, via e-mails, analisadas na pesquisa.

A relação custo-benefício, compreendida como o valor justo pelo serviço ofertado, apresentou um percentual de 5,5\%, observando-se que o mesmo resultado se apresenta para os atributos: atendimento dos funcionários, café da manhã e tamanho do quarto.

Conforme esclarecido nos procedimentos metodológicos, a troca de mensagens entre o diretor da empresa e os clientes segue um padrão. Desse modo, a figura 01, a seguir, apresenta um exemplo de como se processa a troca de informações entre o estabelecimento e os hóspedes.

Figura 01 - Exemplo de feedback utilizado pela empresa

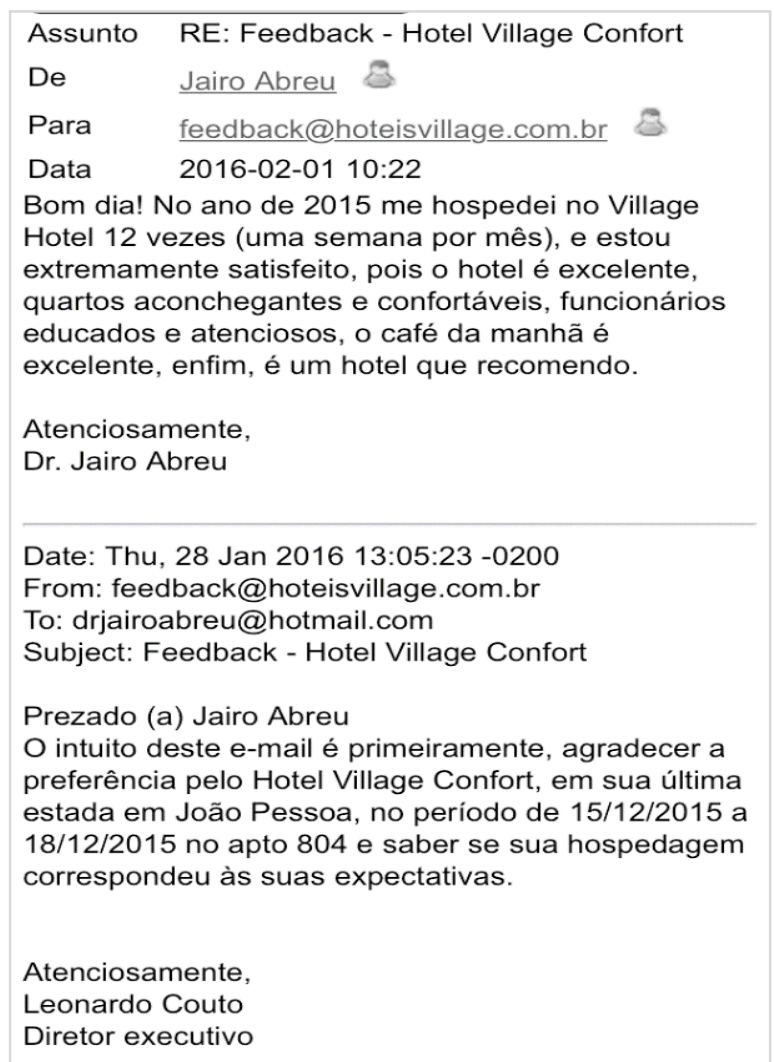

Fonte: Pesquisa dos autores (2017). 


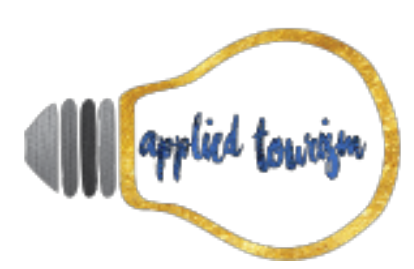

Volume 3, número 1, 2018, p. 93-126

Entretanto, o Village Confort Hotel e Flat, não mantem um sistema de registro da frequência com que os hóspedes utilizam os serviços do hotel, todavia, como o cliente não tem conhecimento desse fato, parece não se importar com o tratamento e responde com grande satisfação. Esse formato de comunicação, segundo informações obtidas no local da pesquisa, é consequência do número limitado de colaboradores do hotel, o que acaba resultando no acúmulo de tarefas, afetando o gerenciamento das reclamações dos clientes.

Kotler \& Keller (2012a) reforçam que a satisfação do cliente parte do julgamento dos resultados percebidos do serviço/produto e a relação de suas expectativas, o que para eles funciona como uma ferramenta para o fortalecimento da confiança. Neste caso, o cliente mostra aparente satisfação com o contato pós-ocupação estabelecido pelo hotel.

Após a constatação de que as mensagens enviadas aos clientes pós-hospedagem eram impessoais, sendo adotada uma abordagem padrão, demonstrando que o estabelecimento não conhecia ou não fazia distinção entre novos hóspedes e os que estavam repetindo a experiência de hospedagem, foram sugeridas pelos pesquisadores, ainda durante a observação direta, algumas medidas para viabilizar uma maior proximidade com o cliente, dentre elas a mudança no texto do e-mail enviado pós-hospedagem, o que foi prontamente acatada conforme observado na figura 02 , apresentada a seguir. 


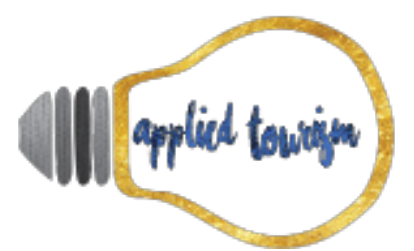

Volume 3, número 1, 2018, p. 93-126

Figura 02 - Conteúdo da mensagem de feedback adotado pela empresa

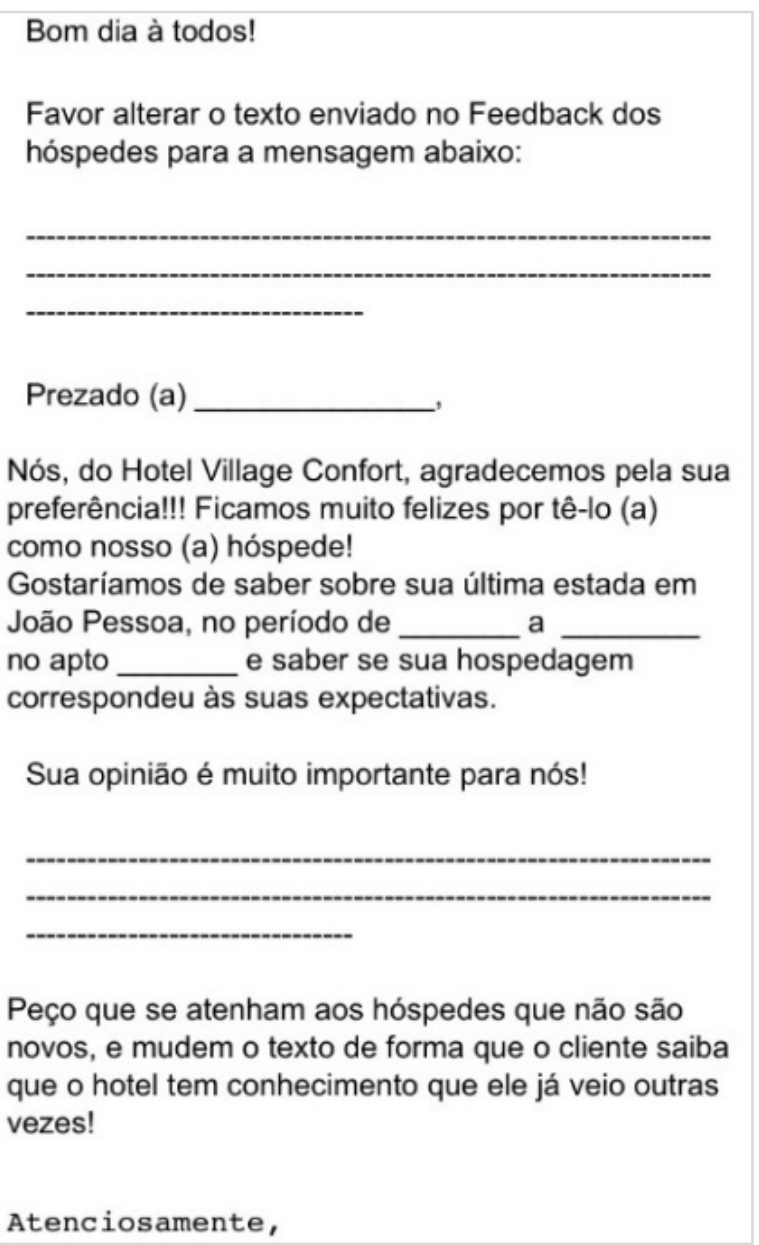

Fonte: Pesquisa dos autores (2017).

Assim, na figura 02, observa-se que o estabelecimento passou a utilizar uma linguagem mais calorosa, direcionando-a individualmente a cada hóspede, procurando estabelecer uma maior aproximação, com a finalidade de construir um relacionamento duradouro e, por consequência, a fidelização desse hóspede.

Em conversa informal com a gerência do setor comercial, foi relatada a dificuldade em identificar os hóspedes mais frequentes, como também, dispor de um colaborador para o desempenho exclusivo dessa atividade, tendo em vista que o hotel pertence a uma rede e seria necessária a criação de um setor específico para esse fim. 


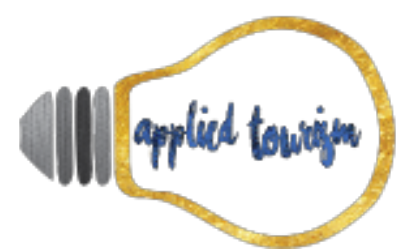

Volume 3, número 1, 2018, p. 93-126

No entanto, a partir das sugestões dos pesquisadores, a gerência designou um dos seus estagiários para assumir a responsabilidade de melhorar a comunicação com os hóspedes já a partir do check-out, sendo recomendado salvar os dados para contato no próprio sistema de informações do hotel para possibilitar o acompanhamento das comunicações pós-hospedagem, permitindo, assim, estabelecer um canal de comunicação atualizado que possibilite 'ouvir' efetivamente o cliente. Entretanto, apesar da boa intenção, a designação de um estagiário para estabelecer um canal eficiente de comunicação com o cliente, talvez não tenha sido a decisão mais apropriada, visto que os estagiários prestam serviços temporários, enquanto as relações com os clientes devem ser duradouras, estabelecidas na perspectiva do longo prazo.

\subsection{Análise dos atributos mencionados no site Booking.com ${ }^{\mathrm{TM}}$}

Esta seção apresenta os resultados da coleta de dados dos atributos estabelecidos pelos pesquisadores em relação aos serviços [comodidade, conforto, limpeza, localização, atendimento, custo benefícios, café da manhã e solicitações] e à estrutura [tamanho do quarto, estrutura geral e instalações] do hotel e de acordo com os comentários registrados no site Booking.com ${ }^{\mathrm{TM}}$ (2017), ressaltando-se que foram registradas 254 menções positivas em relação aos atributos selecionados.

Gráfico 03 - Críticas positivas em relação aos atributos propostos pelos pesquisadores

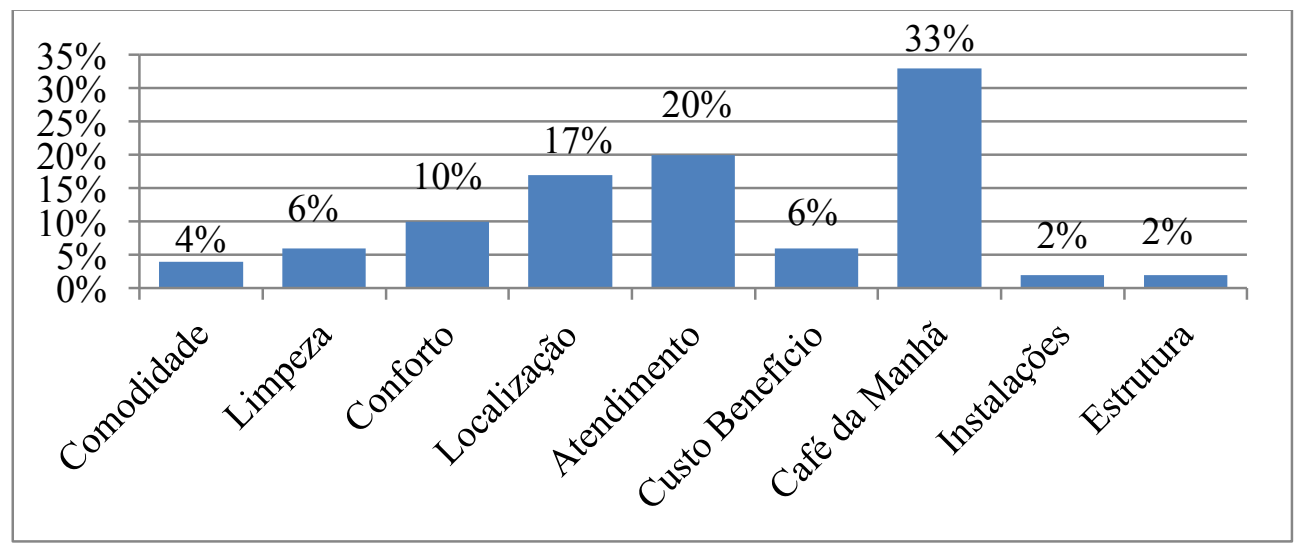

Fonte: Pesquisa dos autores (2017). 


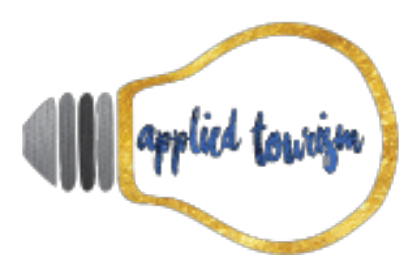

Volume 3, número 1, 2018, p. 93-126

Os dados do gráfico 03 apontam que dentre os atributos mencionados pelos respondentes, o café da manhã apresentou um índice de satisfação de 33\%, enquanto a percepção positiva quanto ao atendimento representou 20\% dos respondentes. De acordo com Dantas (2012), por se tratar de um bem intangível, como é a experiência em serviços de hospitalidade e o produto do consumo são as lembranças, os dois atributos mencionados se apresentam como um ponto forte do hotel.

Também foi possível observar que $27 \%$ dos atributos reconhecidos como positivos do hotel estão relacionados ao conforto e localização, o que atende a proposta do estabelecimento levando em consideração a sua caracterização (Costa, 2008).

Ainda se tratando dos atributos da prestação de serviço, alguns não apresentaram margem percentual expressiva e são pouco relatados no instrumento de pesquisa, a exemplo dos 4\% referentes à comodidade, 6\% à limpeza e igual percentual (6\%) ao custo-benefício.

Observa-se que a percepção positiva em relação aos serviços prestados pelo hotel se sobrepõe ao percentual atribuído aos aspectos físicos, pois do total de respostas apenas $2 \%$ corresponderam à estrutura física e $2 \%$ às instalações, ou seja, os atributos relativos à prestação de serviços chamaram mais a atenção dos respondentes quando do registro de suas experiências.

O gráfico 04, a seguir, apresenta o percentual de descontentamento de alguns clientes em relação à experiência vivida durante a hospedagem. Dos doze atributos propostos no quadro 01, onze foram citados, porém de maneira não tão expressiva quanto às menções positivas, totalizando 89 menções negativas, cerca de um terço quando comparado às menções positivas. 


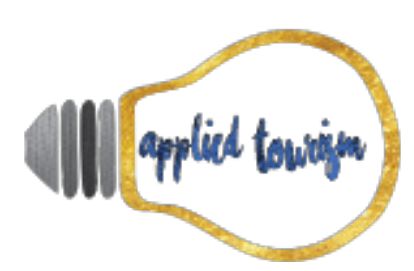

Volume 3, número 1, 2018, p. 93-126

Gráfico 04 - Críticas negativas aos atributos propostos pelos pesquisadores

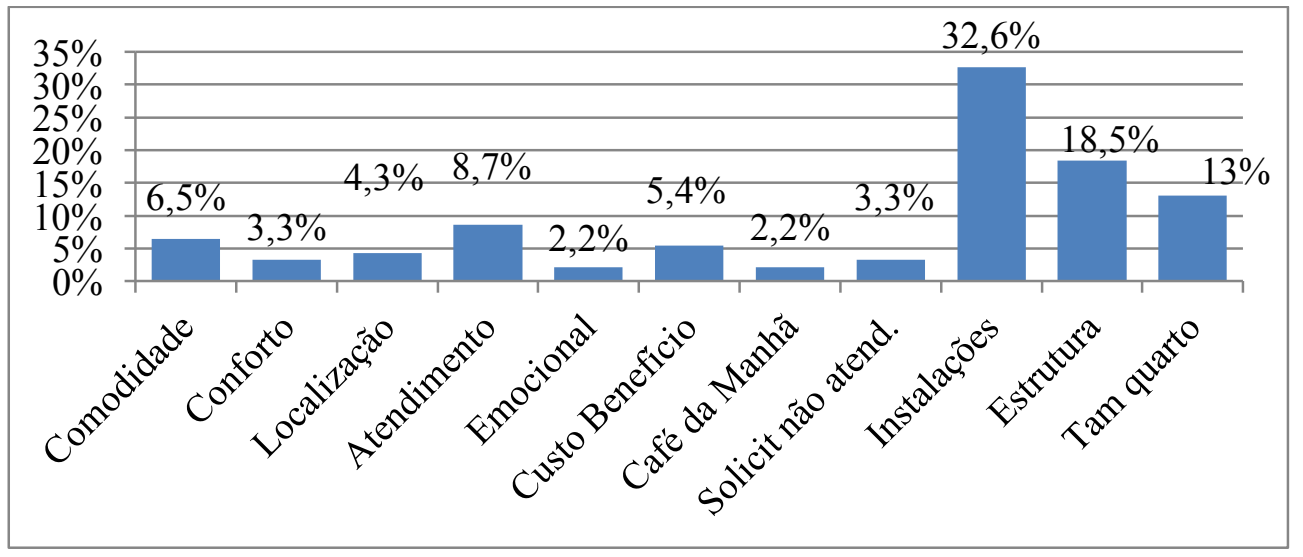

Fonte: Pesquisa dos autores (2017).

A partir dos resultados mostrados no gráfico 04, pode-se observar que as insatisfações relatadas nas reclamações são desfavoráveis quanto à percepção da estrutura física do estabelecimento: 32,6\% das queixas são referentes às instalações, enquanto 18,5\% são relacionadas à estrutura geral do hotel e 13,\% ao tamanho do quarto.

Para Candotte \& Turgeon (1988), a satisfação do cliente pode ser mensurada frente à percepção do bom serviço que lhe foi prestado, e tais atributos de qualidade do serviço não geram expectativas, pois se espera que eles sejam sempre satisfatórios impossibilitando utilizá-los como estimulante da satisfação.

Diante desse cenário, a percepção negativa em relação à qualidade dos serviços prestados pelo hotel irá desenvolver ou incrementar a sua imagem negativa, ainda que em números pouco expressivos. Conforme observado, 8,7\% dos respondentes tiveram impressões negativas relativas ao atendimento dos funcionários; $6,5 \%$ à comodidade; $3,3 \%$ ao conforto; 3,3\% às solicitações não atendidas; 2,2\% apontaram sua percepção negativa em relação ao bem-estar durante a sua estada; e 2,2\% tiveram sua expectativa frustrada quanto ao café da manhã idealizado e esperado. 


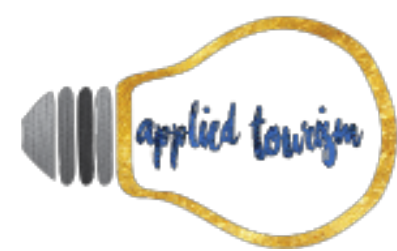

Volume 3, número 1, 2018, p. 93-126

Observou-se também que 5,4\% dos atributos avaliados estão relacionados ao custobenefício e 4,3\% relativo à localização do hotel. O instrumento de pesquisa oferece uma ferramenta de interação entre o cliente que experienciou o serviço e o estabelecimento hoteleiro, permitindo que os clientes potenciais possam avaliar as críticas dispostas publicamente na Internet.

Para Branco, Ribeiro \& Tinoco (2010), é necessária a compreensão da percepção do cliente frente à qualidade do serviço ou produto ofertado para que as expectativas desse cliente sejam atendidas pela empresa. No entanto, em conversa informal com o diretor geral e com o gestor executivo, durante a realização da pesquisa, foi constatado que, ambos desconheciam a possibilidade de interação entre o estabelecimento e o cliente, através dos comentários de feedback registrados pós-hospedagem nos sítios de venda na Internet.

Na figura 03 , apresentada a seguir, observa-se as críticas registradas por um cliente no sítio Booking.com ${ }^{\mathrm{TM}}$ sobre o Village Confort Hotel e Flat, fator que poderá influenciar na tomada de decisão de potenciais clientes ao buscarem informações sobre experiências de hospedagem no referido hotel.

Figura 03 - Crítica de natureza positiva e negativa pelo cliente

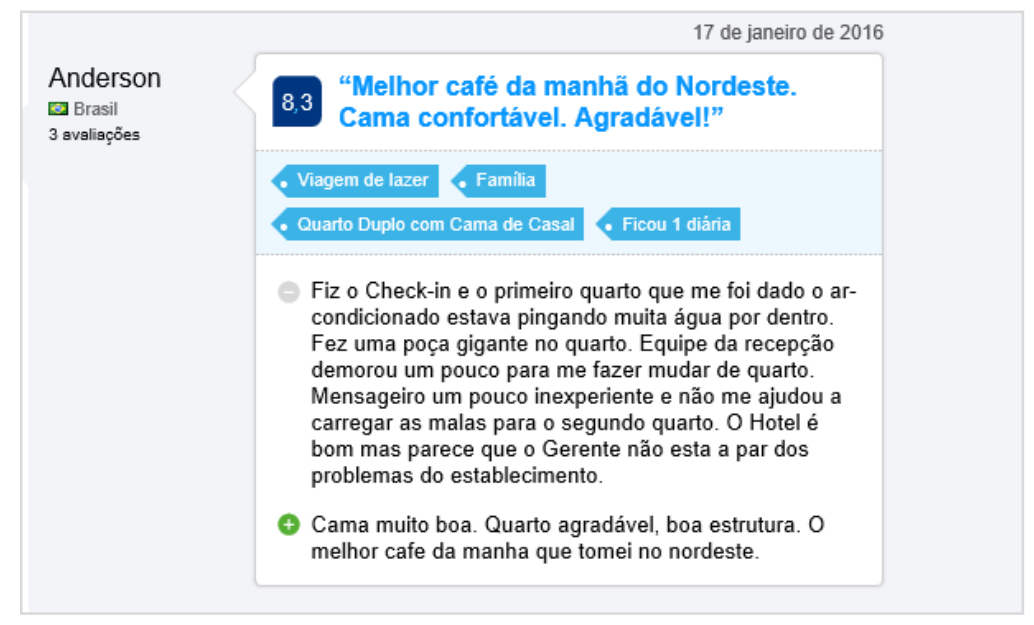

Fonte: Booking.com ${ }^{\mathrm{TM}}$ (2016). 


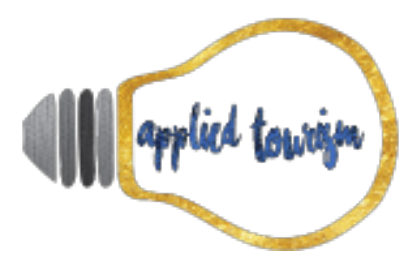

Volume 3, número 1, 2018, p. 93-126

Para Barbosa et al. (2011), a percepção positiva em relação ao gerenciamento e administração do hotel contribuem para a imagem e o sucesso econômico do estabelecimento. Por sua vez, na figura 04, abaixo, é apresentado, como exemplo, uma parte do questionário utilizado para realização desse estudo.

Figura 04 - Exemplo de resposta ao instrumento de pesquisa.

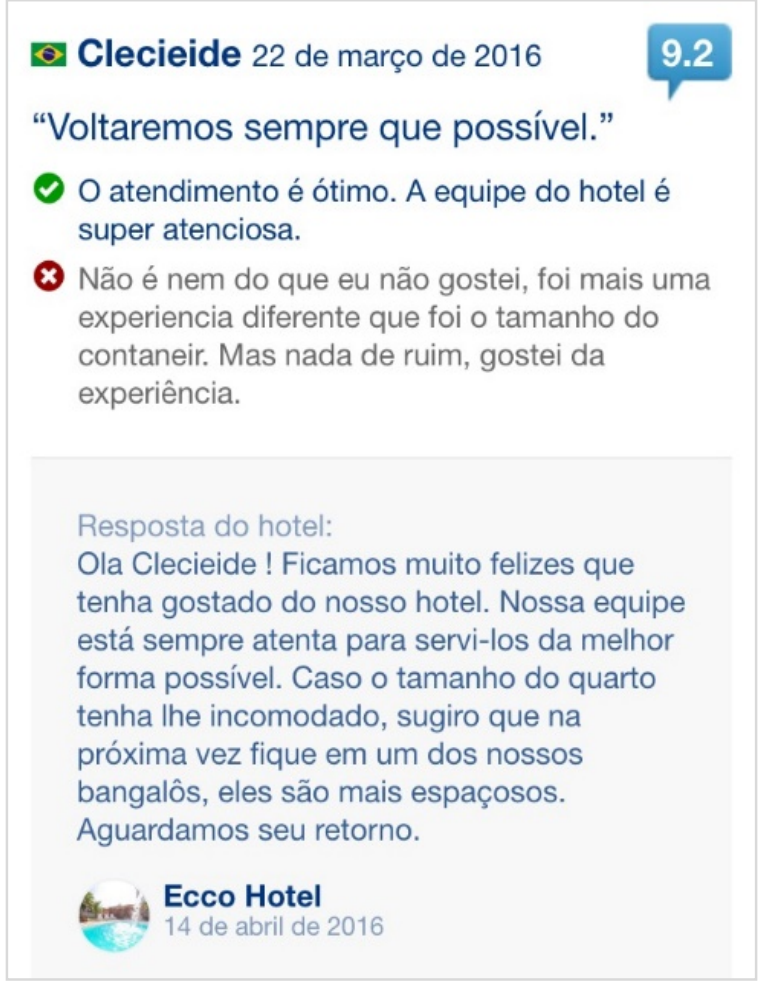

Fonte: Booking.com ${ }^{\mathrm{TM}}$ (2016).

Cabe registrar que, no período em que os dados desse estudo foram coletados no instrumento de pesquisa do Village Confort Hotel e Flat, outro estabelecimento pertencente à Rede de Hotéis Village, o Ecco Hotel, fez uso do mesmo instrumento de pesquisa para obter retorno de informações pós-hospedagem, o que evidencia que a gestão das reclamações dessa rede de hotéis não segue um padrão estabelecido pela direção executiva e que o gestor de cada unidade da rede decide por utilizar ou não essa ferramenta, o que poderá acarretar distorções nas informações registradas nos relatórios de gerenciamento da experiência do cliente, afetando as possíveis ações corretivas. 


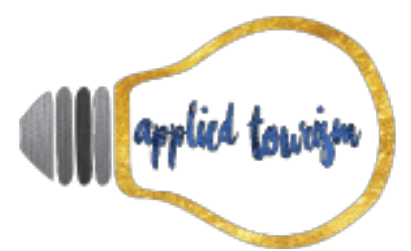

Volume 3, número 1, 2018, p. 93-126

\subsection{Análise dos atributos mencionados no site TripAdvisor}

Esta seção apresenta os resultados da coleta de dados dos atributos estabelecidos pelos pesquisadores em relação aos serviços [comodidade, conforto, limpeza, localização, atendimento, custo benefícios, café da manhã e solicitações] e à estrutura [tamanho do quarto, estrutura geral e instalações] do hotel e de acordo com os comentários registrados no site TripAdvisor $@$ (2017), ressaltando-se que foram registradas 114 menções positivas em relação aos doze atributos dispostos e 27 referências negativas.

Os dados do gráfico 05 abaixo mostra que a qualidade dos serviços prestados está dentro do esperado: 18,5\% dos atributos citados são referentes ao atendimento dos funcionários, sendo reconhecido como um atributo de qualidade.

Gráfico 05 - Críticas positivas em relação aos atributos propostos pelos pesquisadores

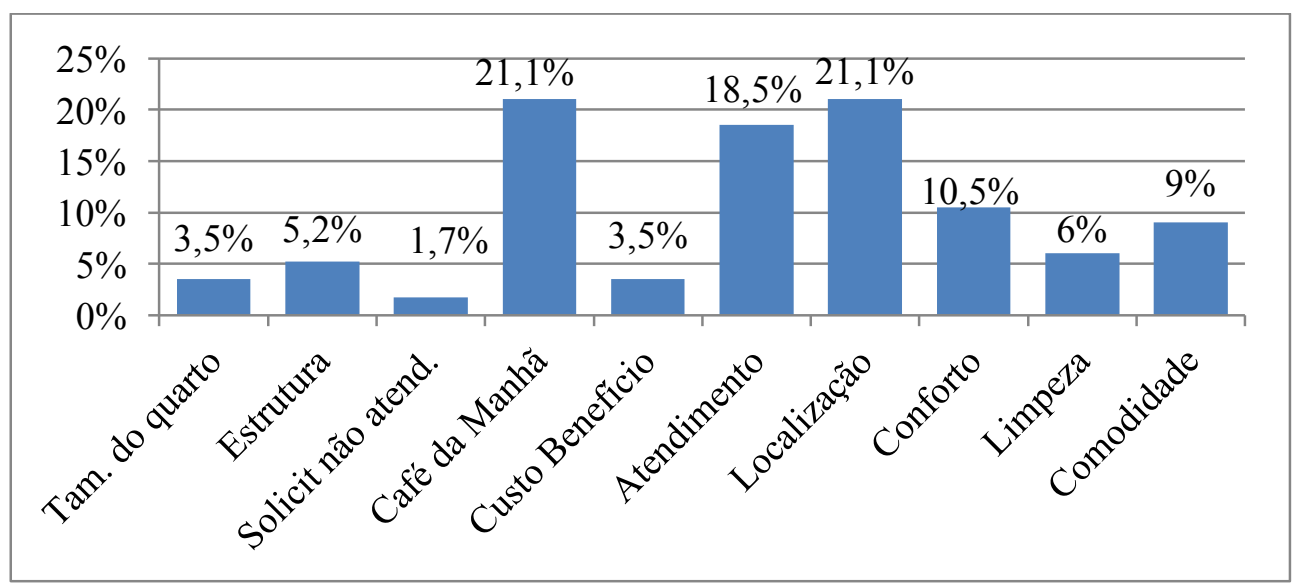

Fonte: Pesquisa dos autores (2017).

Castelli (2016a), considera a localização como um ponto forte, além de primordial em hotéis econômicos, como é o caso do estabelecimento em estudo: 21,1\% dos registros de satisfação são referentes ao atributo localização. Os resultados também mostram que 21\% dos registros mencionaram o café da manhã como atributo positivo e satisfatório; 10,5\% o conforto e 9\% a comodidade. Apenas 6\% são relativos à limpeza e 5,2\% está ligado à percepção positiva da estrutura física do estabelecimento. Os atributos, custo-benefício e 


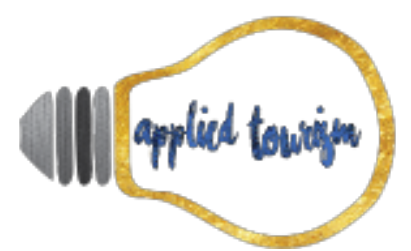

Volume 3, número 1, 2018, p. 93-126

tamanho do quarto repetiram o mesmo resultado (3,5\%); o atributo solicitações atendidas, representaram apenas $1,7 \%$, sendo pouco expressivo.

No gráfico 06, abaixo, os dados revelaram que 26\% dos respondentes avaliaram negativamente a estrutura física do hotel e 18,6\% as instalações, apresentando-se como um critério que potencializa a insatisfação do cliente com o produto/serviço prestado.

Gráfico 06 - Críticas negativas em relação aos atributos propostos pelos pesquisadores

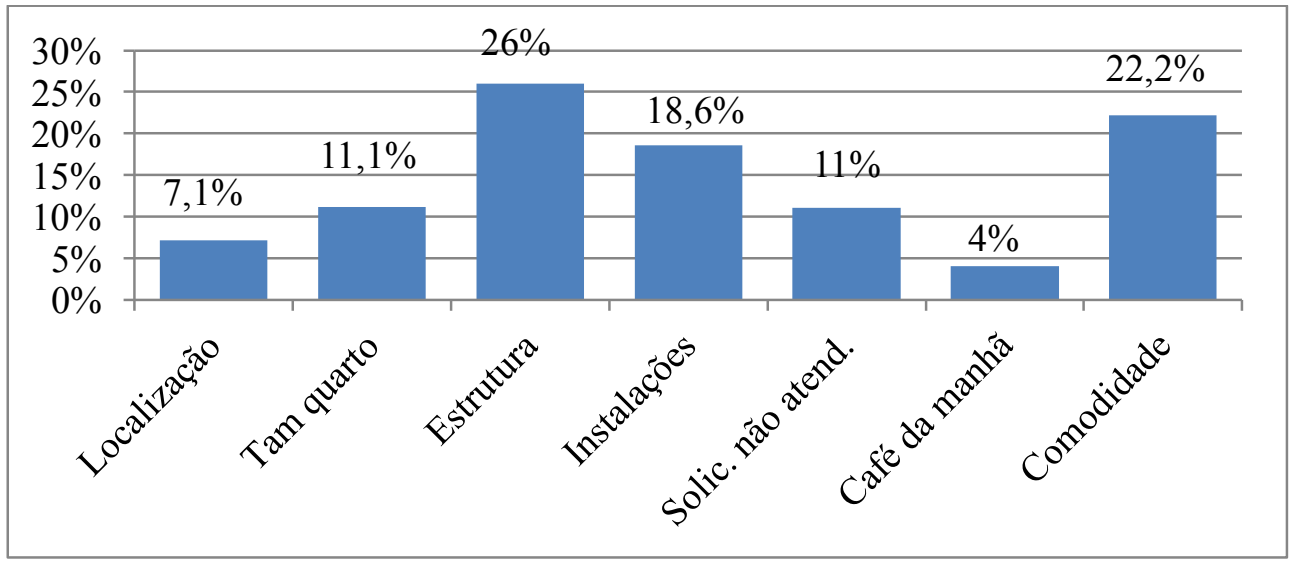

Fonte: Pesquisa dos autores (2017).

Em relação aos aspectos acima expostos, observou-se durante a pesquisa in lócus que, algumas das críticas negativas em relação à estrutura e às instalações diziam respeito a odores exalados dos ralos do banheiro, a presença de mofo e infiltrações, além de problemas com vazamentos no box dos banheiros e nos equipamentos de ar-condicionado. Em conversa com o gestor do estabelecimento, constatou-se que mediante o registro desse tipo de reclamação, a equipe do hotel está orientada a trocar o cliente de apartamento e até que o devido reparo seja efetuado, o apartamento que apresentou problema fica bloqueado.

Comparando-se os dados dos gráficos 05 e 06 foi possível observar que o grau de insatisfação com as solicitações não atendidas dos hóspedes é maior que o grau de satisfação. Em comparação tem-se: 11\% de resultado insatisfatório contra 1,7\% satisfatório. Em 22,2\% dos registros, o atributo comodidade também apresenta um valor maior que o 


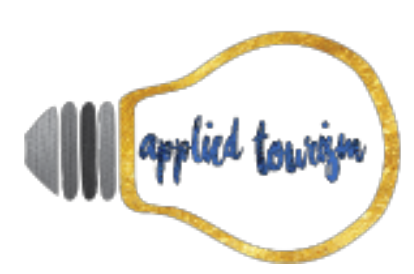

Volume 3, número 1, 2018, p. 93-126

mesmo item no gráfico 05 de críticas positivas. Em contrapartida, a insatisfação com o atributo café da manhã totalizou 4\% e a localização do hotel 7\%, resultados bem inferiores àqueles mencionados como atributo positivo no gráfico anterior.

\subsection{Resultado das análises dos atributos mencionados nos questionários} avaliativos

Esta seção apresenta os resultados alcançados a partir da análise dos questionários avaliativos dos serviços do Village Confort Hotel e Flat, aplicados com os hóspedes que se dispuseram voluntariamente a participar da pesquisa no momento do check-out. Os questionários foram elaborados e dispostos no balcão do estabelecimento sem a interferência dos pesquisadores.

Considerando a necessidade de analisar todos os canais de comunicação, os questionários disponibilizados na recepção do hotel também foram considerados como fonte de dados. Constatou-se que, o instrumento de pesquisa supracitado não é tão utilizado pelos hotéis da Rede Village, quando comparados com os demais canais já analisados, visto que no período de três meses de coleta de dados apenas 23 questionários foram respondidos.

O gráfico 07 apresentado abaixo buscou mostrar a satisfação dos clientes em relação aos serviços oferecidos pelo hotel, sendo o conforto do apartamento o atributo apontado como 'excelente' por $56,5 \%$ dos pesquisado, enquanto $26,9 \%$ classificaram esse atributo como 'bom'. 


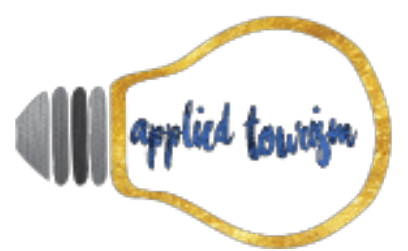

Volume 3, número 1, 2018, p. 93-126

Gráfico 07 - Satisfação dos clientes em relação à experiência de hospedagem

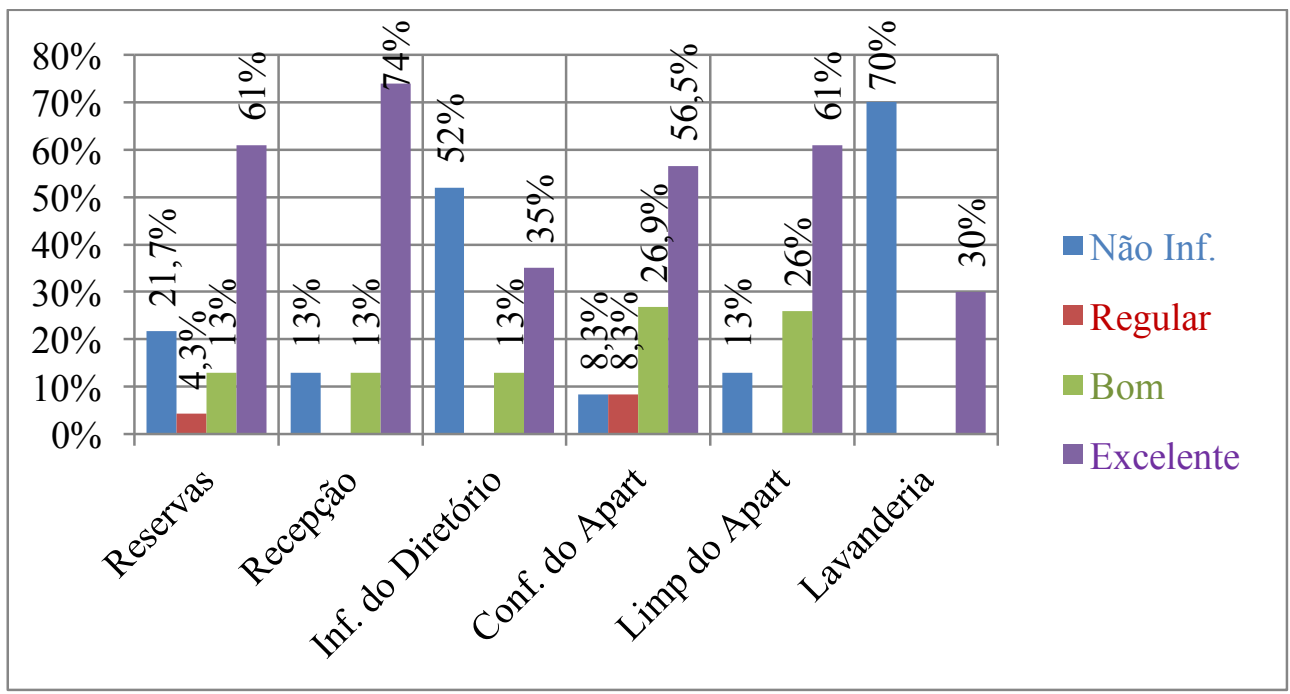

Fonte: Pesquisa dos autores (2017).

É possível observar também que, os clientes se declararam bastante satisfeitos não tendo relato negativo de satisfação com a prestação do serviço. Assim, de acordo com os dados do gráfico 07 , observou-se que: $74 \%$ dos respondentes consideram excelente o atendimento da recepção; 13\% avalia como regular; e 13\% não informaram. Tais percentuais, fortalecem o conceito de percepção de qualidade defendido por Fitzsimmos \& Fitzsimmos (2014).

O hotel também oferece serviço terceirizado de lavanderia, avaliado por $30 \%$ dos clientes como excelente o que mostra ser um fator positivo, cabendo ressaltar que não houve avaliação negativa em relação a esse atributo, porém 70\% não informaram ou não utilizaram os serviços.

Dos clientes que utilizaram os serviços de reservas 61\% atribuíram conceito 'excelente' e 13\% 'bom', 4,3\% considerou 'regular' o que não representa margem expressiva. Os que não manifestaram qualquer opinião representou $21,7 \%$ dos pesquisados.

Os que avaliaram como 'regular' ou que não opinaram a respeito apresentaram resultados semelhantes de 8,3\%. A limpeza do apartamento apresentou apenas conceitos positivos 


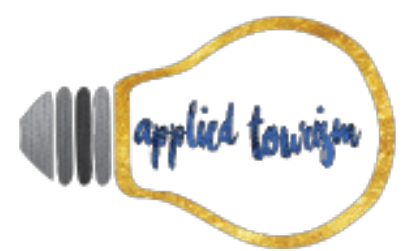

Volume 3, número 1, 2018, p. 93-126

sendo 61\% 'excelente' e 26\% ‘bom'. Em 13\% dos questionários avaliativos não haviam opção marcada para este item. Quanto às informações do diretório 52\% não informaram ou não perceberam, 35\% conceituaram como excelente e 13\% como bom.

Os dados do gráfico 8, a seguir, correspondem à satisfação dos clientes em relação ao atendimento dos funcionários e registrou três tipos de percepções: excelente, bom e não informou.

Gráfico 08 - Grau de satisfação do cliente em relação ao atendimento dos funcionários

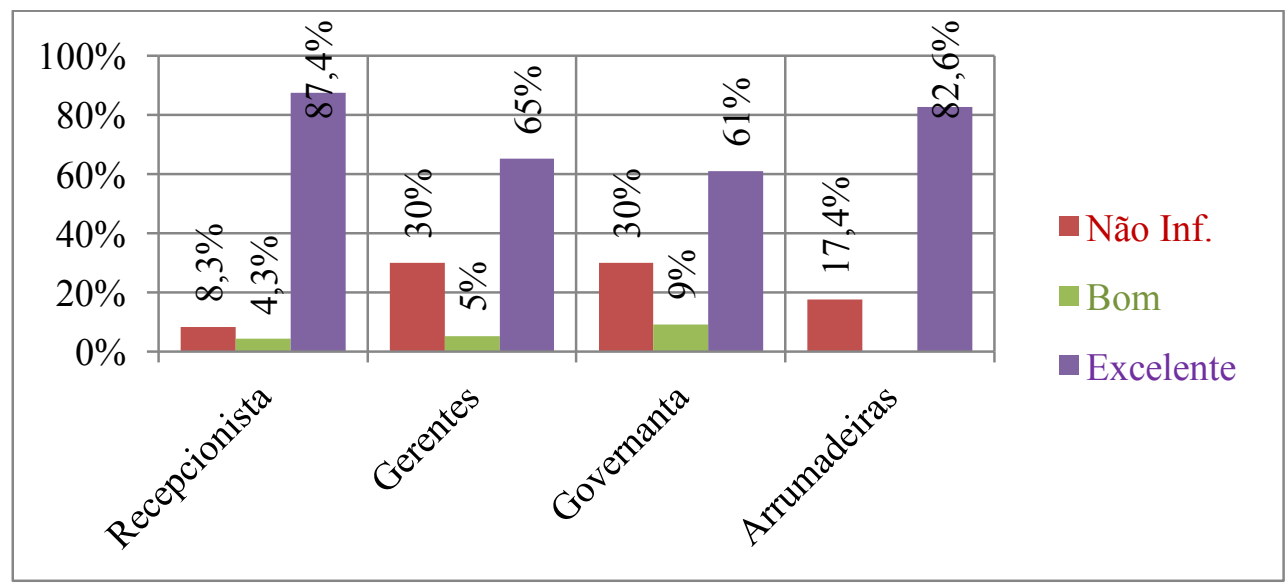

Fonte: Pesquisa dos autores (2017).

As opções: regular e fraco, não apareceram nas avaliações pelos hóspedes. Seguindo a ordem de percepção do maior para o menor resultado, constatou-se que os recepcionistas com 87,4\% receberam o conceito 'excelente'; seguidos das arrumadeiras com 82,6\%; o gerente com $65 \%$; e a governanta com $61 \%$.

Já o conceito 'bom', para os funcionários recepcionistas foi bastante baixo, pois corresponderam a 4,3\%; para a governanta 9\%; para o gerente 5\%; e para as arrumadeiras não foi informado. Dos questionários respondidos, $60 \%$ não informaram sobre 0 desempenho do gerente e da governanta; 17,4\% o desempenho das arrumadeiras; e 8,3\% do recepcionista.

O gráfico 09, abaixo, mostra a satisfação dos clientes com a qualidade e o consumo de alimentos e bebidas dentro do estabelecimento. 


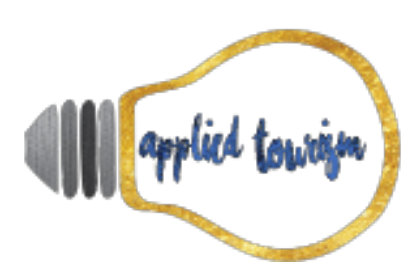

Volume 3, número 1, 2018, p. 93-126

Gráfico 09 - Satisfação do cliente em relação ao consumo de alimentos e bebidas

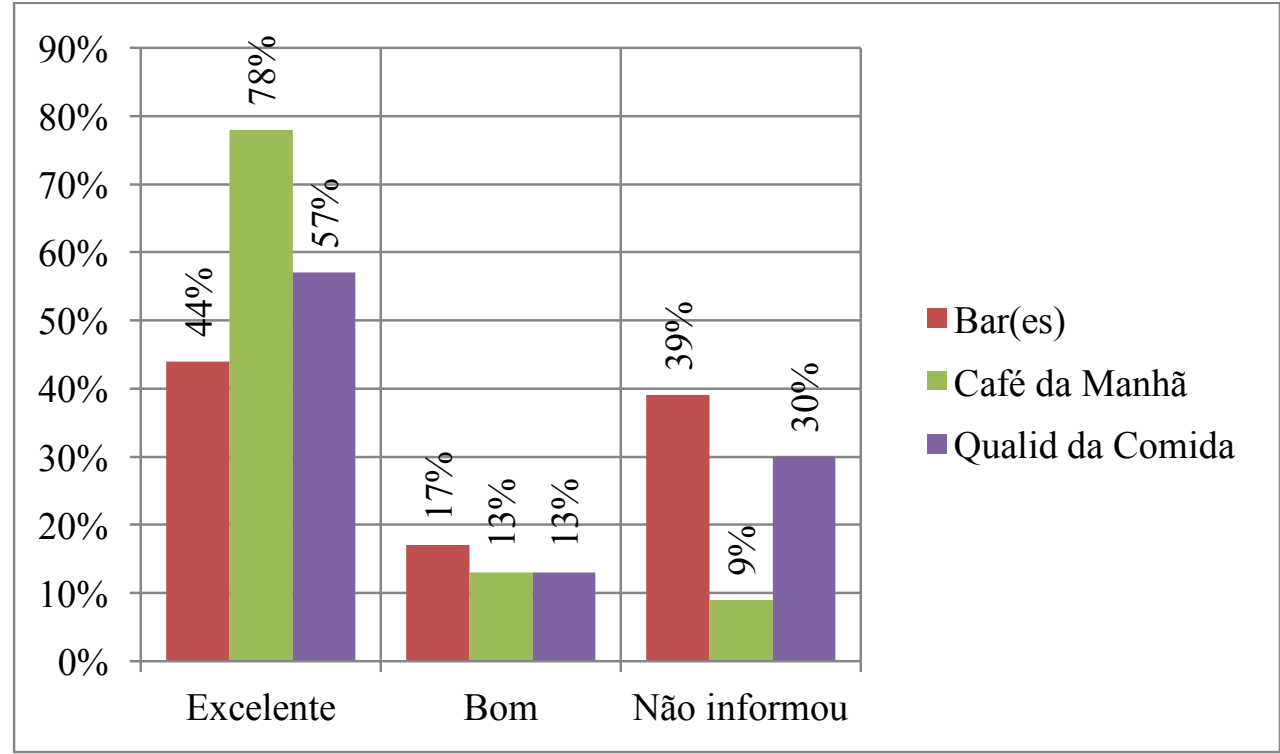

Fonte: Pesquisa dos autores (2017).

Dos questionários coletados e analisados, o atributo 'café da manhã' foi avaliado como 'excelente': 78\% das respostas, se comparados ao conceito de bom com 13\% e os 9\% que não informaram. Também se infere que, a qualidade da comida obteve avaliação 'excelente' com 57\% e 'bom' com 13\%. Foi de 30\% o percentual de questionários que não apresentavam respostas para esse atributo. O bar do hotel foi conceituado como 'excelente' para 44\% dos respondentes; 17\% avaliaram como 'bom'; e 39\% alegaram não ter utilizado ou não informaram.

Os questionários avaliativos também elencaram questões sobre a satisfação dos hóspedes com a capital João Pessoa-PB e com o hotel, conforme se observa no gráfico 10 abaixo. 


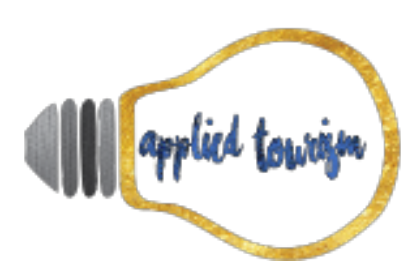

Volume 3, número 1, 2018, p. 93-126

Gráfico 10 - Satisfação do cliente em relação à cidade e ao hotel

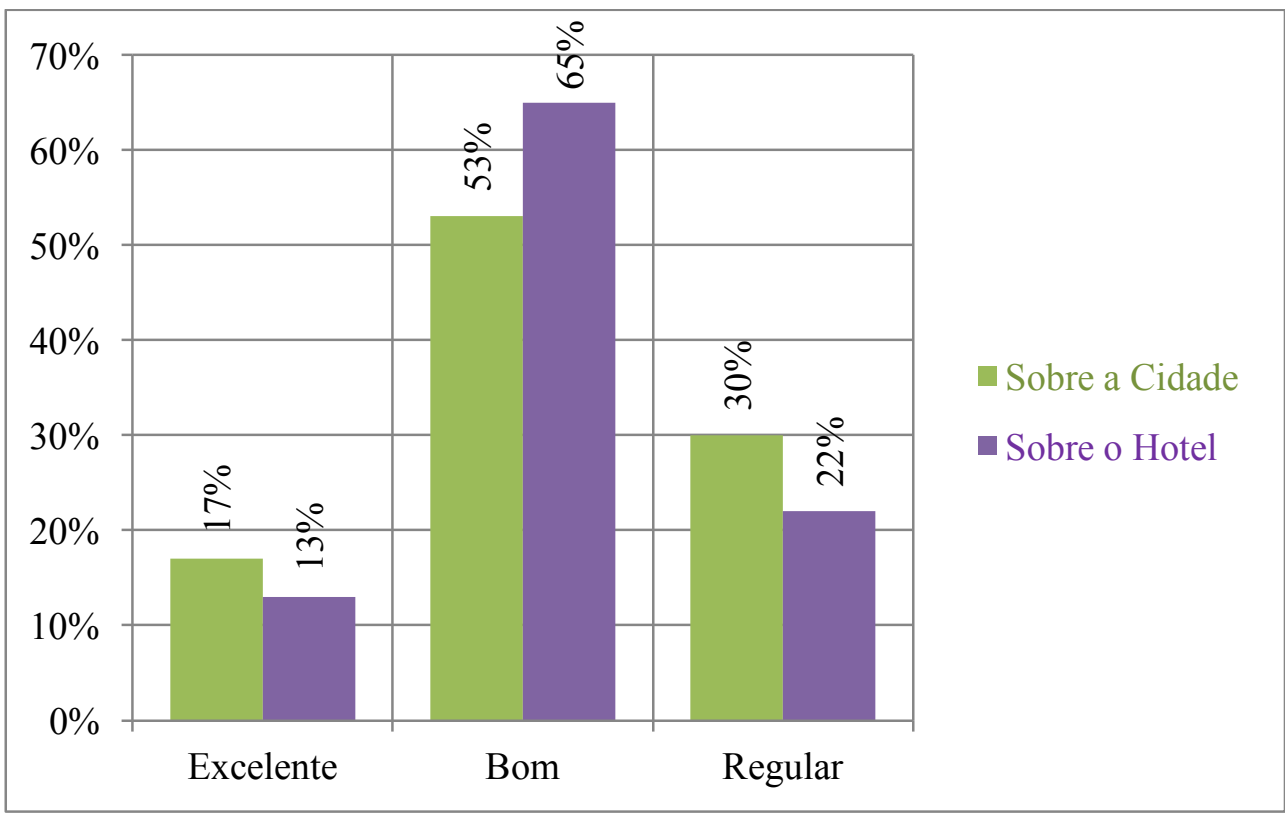

Fonte: Pesquisa dos autores (2017).

Dessa forma, de acordo com o gráfico 10, no item sobre a satisfação dos hóspedes com a cidade, $53 \%$ dos pesquisados atribuíram o conceito 'bom'; 30\% 'regular' e 17\% 'excelente'. Já a percepção sobre o hotel, os dados revelaram que 65\% dos hóspedes conceituaram o hotel como 'bom'; 22\% como 'regular' e 13\% como 'excelente'.

A pesquisa também buscou identificar as motivações dos pesquisados para a estada em João Pessoa: 74\% alegou estar a passeio; 13\% a negócios; 8\% não informou; e 4\% vieram pelos dois motivos.

De maneira geral, os resultados apresentados no feedback eletrônico da empresa foram significativamente positivos quanto à qualidade dos serviços, pois 30,8\% dos atributos citados referem-se ao bom atendimento dos funcionários; $27,6 \%$ ao café da manhã; 10,76\% a estrutura do hotel; 9,23\% ao conforto; 6,15\% à localização; 4,6\% à limpeza; os atributos relativos a comodidade, instalações e bem-estar apresentaram resultados semelhantes apenas 3,1\%; e, por fim, 1,5\% dos atributos citados foram referente a satisfação com o tamanho do quarto. 


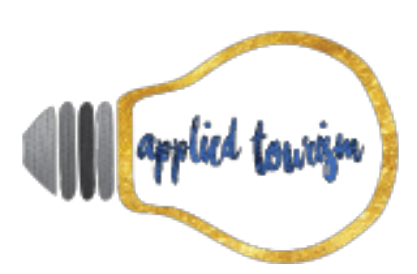

Volume 3, número 1, 2018, p. 93-126

Os atributos mencionados nos e-mails também tinham caráter negativo, sendo 44,4\% deles referente às instalações, 16,6\% referente a estrutura física, semelhantemente ao percentual das solicitações que não foram atendidas.

Por fim, cabe destacar que, o frequente contato com os gerentes executivos do estabelecimento propiciaram aos pesquisadores sugerir e apresentar suas observações, à medida que, a pesquisa era desenvolvida, o que resultou na adoção imediata das sugestões pela gerência, contribuindo significativamente para a gestão empresarial e a inteligência nos negócios.

\section{CONSIDERAÇÕES FINAIS}

Esse estudo objetivou conhecer a relação da experiência em serviços de hospitalidade e as diretrizes tomadas pelos gestores do Village Confort Hotel e Flat a partir dos comentários (positivos e/ou negativos) mencionados pelos hóspedes por meio dos mecanismos de avaliação dos serviços mais utilizados por essa rede de hotéis.

Os resultados alcançados mostraram que o hotel apresenta uma relação de atributos e fatores que impactam positivamente sobre a satisfação do cliente em relação à percepção da qualidade do serviço e do produto consumido no período de estada dos hóspedes, porém, há uma série de recorrências nas reclamações dos clientes e alguns casos parecem estar fora de controle, a exemplo do odor que exalava do banheiro dos apartamentos.

Foi constatado também que o hotel não delegava a responsabilidade de tratar a relação com o hóspede e o registro de reclamações a uma pessoa específica, estando o gerenciamento das reclamações centrado nas mãos do diretor executivo do hotel e do gerente. Segundo relato do diretor, em conversa informal com os pesquisadores, à medida que as reclamações ou elogios surgem, ele os classifica em pouco importante, importante e bastante importante, sendo assim, algumas críticas não são do conhecimento dos funcionários. 


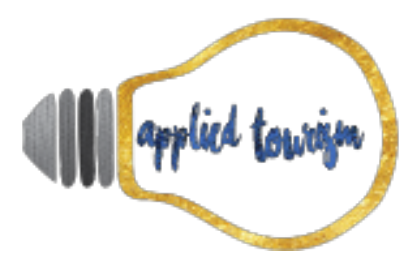

Volume 3, número 1, 2018, p. 93-126

Outro ponto observado foi que no estabelecimento pesquisado, os gestores não utilizam os mecanismos de comunicação com o cliente [dispostos no instrumento de pesquisa], ficando as críticas, positivas ou negativas, ao estabelecimento sem um feedback adequado por parte da gerência, sendo adotada apenas uma resposta padrão sem considerar as peculiaridades das observações feitas pelos clientes.

Entretanto, esse mesmo mecanismo é utilizado por outro estabelecimento da mesma rede, sob mesma direção, o que se configura como um problema, levando em consideração que o consumidor poderá visualizar os estabelecimentos que pretende ficar e perceber que apenas um estabelecimento aparenta estar preocupado com o consumidor. Uma sugestão de solução para este problema seria a contração de uma pessoa que ficasse responsável para identificar e realizar a comunicação com os clientes, informando à gerência para que sejam tomadas as providências cabíveis em cada caso.

Para o estabelecimento, não basta apenas identificar e discutir os problemas apontados pelos usuários da Rede de Hotéis Village: isso seria apenas o primeiro passo para a melhoria da qualidade dos serviços. É essencial que o gerenciamento da experiência do cliente seja utilizado como ferramenta norteadora de ações corretivas, sobretudo quando se leva em consideração a dimensão exponencial alcançada pelo uso das redes sociais e pelos sites que registram as percepções dos consumidores sobre suas experiências, afinal, o bom e velho recurso do boca em boca, ou marketing de referência, ainda se configura como importante canal de comunicação entre as empresas e seus clientes/consumidores.

\section{REFERÊNCIAS}

Barbosa, M. de L. A., Souza A. G. de., Kovacs, M. H., \& Melo, L. da S. A. (2011). Gestão da experiência de serviços de hospitalidade: o que a empresa propõe e qual o significado para o consumidor. In: Revista Acadêmica do Observatório de Inovação do Turismo, Rio de Janeiro-RJ, v. 6, n. 2, pp. 1-15, jun.

Beni, M. C. (2006). Política e planejamento de turismo no Brasil. 1 ed. São Paulo: Aleph.

Booking.com ${ }^{\mathrm{TM}}$. (2017). Village Confort Hotel e Flat. Acesso em 14 de abril de 2017, disponível em: $<$ https://www.booking.com/searchresults.pt-br.html?aid=376377;label= booking- 


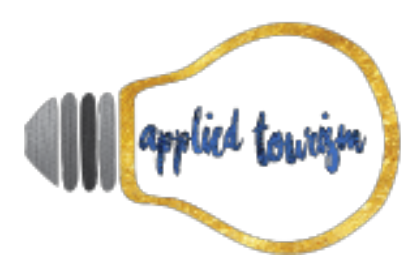

Volume 3, número 1, 2018, p. 93-126

name-

ptrowBebSrDpYXzat\%2AXUq7s611wS144456251211\%3Apl\%3Ata\%3Ap1\%3Ap21.212.000\% 3Aac\%3Aap1t1\%3Aneg\%3Afi\%3Atiaud85284111486\%3Akwd65526620\%3Alp1001621\%3Ali \%3Adec\%3Adm;sid=338bee0d46e5edf958beef48017a113c;city = -

649584; expand_sb=1;highlighted_hotels $=323902 ; \mathrm{hlrd}=$ no_dates;keep_landing $=1 ;$ re directed $=1 ;$ source $=$ hotel $\& \#$ hotelTmpl $>$.

Branco, G. M., Ribeiro, J. L. D., \& Tinoco, M. A. C. (2010). Determinantes da satisfação e atributos da qualidade em serviços de hotelaria. In: Revista Produção, São Paulo-SP, v. 20, n. 4, pp. 576588, out./dec.

Cadotte, E. R., \& Turgeon, N. (1988). Key factors in guest satisfaction. In: Cornell Hotel and Restaurant Administration Quarterly, New York-USA, v. 28, n. 4, pp. 44-51, feb.

Campos, L. C. de A. M., \& Gonçalves, M. H. B. (1998). Introdução a turismo e hotelaria. 1 ed. de Janeiro: Senac Nacional.

Castelli, G. (2016a). Gestão Hoteleira. 2 ed. São Paulo: Saraiva.

. (2005b). Hospitalidade: na perspectiva da gastronomia e da hotelaria. 1 ed. São Paulo: Saraiva.

Cooper, C. (2007). Turismo: Princípios de Práticas. Tradução de Alexandre Salvaterra. 3 ed. Porto Alegre: Bookman.

Costa, A. (2008). Relações públicas e hotelaria. Acesso em 10 de março de 2017, disponível em: $<$ http://www.portaleducacao.com.br/turismo-e-hotelaria/artigos/6327/empresashoteleiras\%20processo-de-comunicacao\#ixzz44K5MBGGR>.

Daft, R. L. (2009). Administração. 1 ed. São Paulo: Cengage Learning.

Dantas, E. B. (2012). Atendimento ao público nas organizações. 6 ed. Brasília: Senac. 


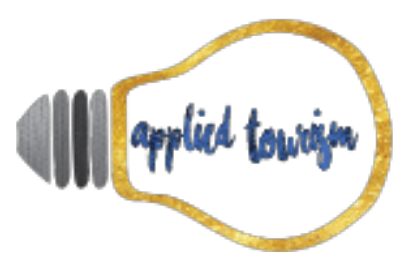

Volume 3, número 1, 2018, p. 93-126

Fitzsimmons, J. A., \& Fitzsimmons, M. J. (2014). Administração de serviços: operações, estratégia e tecnologia da Informação. 7 ed. Porto Alegre: AMGH.

González, M. O. A., Ramos, R. E. B., \& Amorim, C. G. (2005). Gestão da satisfação e da fidelidade do cliente na hotelaria: um estudo dos fatores que influenciam a satisfação e a fidelidade do turista internacional. In: Anais... XXV Encontro Nacional de Engenharia de Produção, Porto Alegre, RS, Brasil, pp. 1685-1692, out./nov.

Holbrook, M. B. (2000). The millennial consumer in the texts of our times: experience and entertainment. In: Journal of Macromarketing, Estados Unidos-EUA, v. 20, n. 2, pp. 176192, dez.

Kotler, P., \& Keller, K. L. (2012a). Administração de marketing. 14 ed. São Paulo: Pearson Hall.

. (2007b). Administração de marketing. 12 ed. São Paulo: Pearson Hall.

Lashley, C., \& Morrison, A. (2004). Em busca da hospitalidade: Perspectivas para um mundo globalizado. Tradução de Carlos David Szlak. 1 ed. Barueri: Manole.

Oliveira, F. F. de. (2008). Comportamento do consumidor: um estudo das teorias de marketing aplicadas ao turismo. Acesso em 21 de agosto de 2017, disponível em: $<$ http://goo.gl/hP0NLp>.

Tischeler, A. M., Albarello, C. B., Brandt, G. T., Ferronatto, J. C., Goettems, L. C. M., \& Alcântara, M. de. (2012). Marketing de relacionamento: gestão de experiência do cliente. In: Revista de Administração, Frederico Westphalen-RS, v. 10, n. 17, pp. 90-101, mar.

Trigueiro, K. (2003). Novas tendências do consumidor de turismo na nova economia. Acesso em 21 de agosto de 2017, disponível em: < http://www.setur.ufop.br/artigo01.pdf> .

TripAdvisor@ (2017). Village Confort Hotel e Flat. Acesso em 10 de abril de 2017, disponível em: $<$ https://www.tripadvisor.com.br/Hotel_Review-g303428-d2520494-ReviewsHotel_Village_Confort_Joao_Pessoa-Joao_Pessoa_State_of_Paraiba.html>. 